Historic, archived document

Do not assume content reflects current scientific knowledge, policies, or practices. 



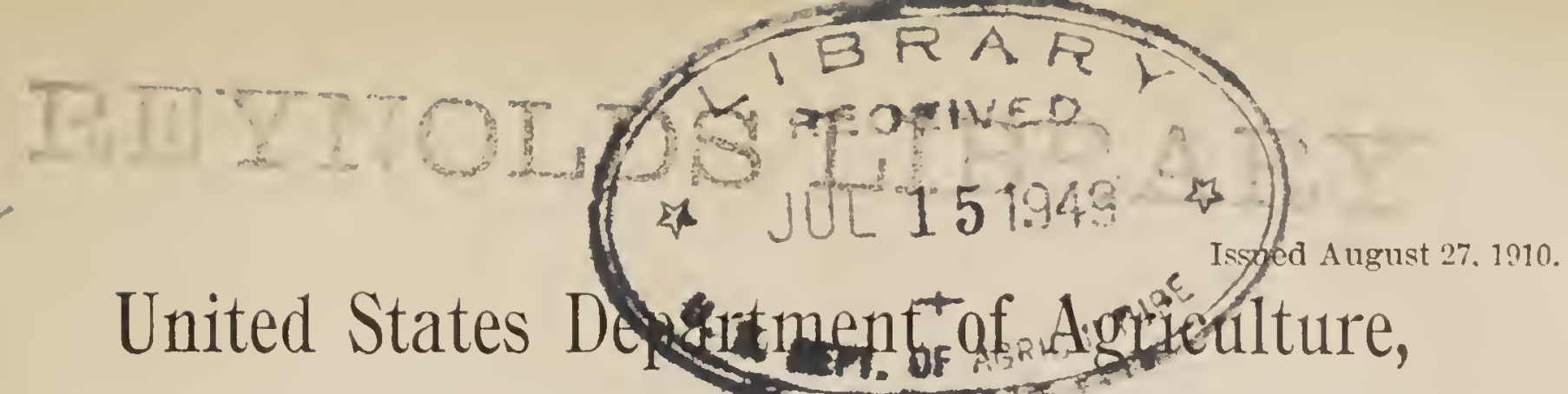

BUREAU OF BIOLOGICAL SURVEY-Circular No. 74.

H. W. HENSHAW, Chief of Bureau.

\section{DIRECTORY OF OFFICIALS AND ORGANIZATIONS CONCERNED WITH THE PROTECTION OF BIRDS ANI GAME, 1910.}

The eleventh annual directorr of officials and organizations concerned with the protection of birds and game in the United States and Canada has been arranged on the same plan as the directories issucd each year since 1900, and has been revised to July 15, 1910. The addresses are grouped under four headings-State Officials, National Organizations, State Organizations, and Audubon Societies.

The object of this directory is to present, in convenient form, the names of persons to whom application may be made for information respecting game laws. It also shows the date of establishment of each State commission or wardenship, the changes which occur in such offices, and the publications issued by game officials. As many of the present fish and game commissions originated as fish commissions, the year when each was established and that in which it assumed jurisdiction of game are given.

In 42 States the enforcement of game laws is intrusted to game commissioners, wardens, or other State officers; in 5 others-Florida, Georgia, Kentucky, Mississippi, and Nevada-to county wardens; in Virginia to city and magisterial district wardens; in Arkansas to sheriffs and similar local officers; and in the District of Columbia to the Metropolitan Police. The first special State officials charged with preservation of game were the moose wardens appointed in Maine in 1852 and the ducking police of Maryland appointed in 1872. The first State commissions whose jurisdiction was extended to include this work were the fish commissions of California and New Hampshire in 1S78. Several national organizations are interested in the protection of birds and game, of which two are really international. In addition, State associations and many local organizations cooperate in the work of protecting game in 28 States. One of these associations was organized in 1844, another in 1865, and 3 other's were established more than twenty-five years ago. Similar organizations have been formed in 8 Provinces of Canada, of which one in Nova Scotia was established in 1853 and one in Quebec in 1859. Finally, 37 States have Audubon Societies, organized especially for the study and protection of nongame birds.

Persons interested in game protection are requested to notify the Biological Survey of any errors or changes in addresses in order that necessary corrections may be made in future editions of the directory.

Approved: T. S. PAlMER, Assistant Chief', Biological Survey.

JAMES WILSON,

Secretary of Agriculture.

a Previous editions of this directory have been published as circulars of the Biological survey as follows: 1900, No. 28; 1901, No. 33; 1902, No. 35; 1903, No. 40; 1904, No. 44; 1905, No. 50; 1906. No. 5.3; 1907, No. 62; 1908, No. 65; 1909, No. 70.

$534 \mathrm{S6}^{\circ}$-Cir. $74-10$ 


\section{FEDERAL OFFICIALS.}

UNITED STATES DEPARTMENT OF AGRICULTURE.

[Jurisdiction extended to game protection by Act of May 25, 1900.]

Secretary of Agriculture, James Wilson, Washington, D. C.

Chief of Biological Survey, H. W. Henshaw, Washington, D. C.

Assistant Chief, Biological Survey, T. S. Palmer, Washington, D. C.

\section{STATE OFFICIALS.}

[For information respecting the game laws in States and Territories which have no State wardens address as follows: Alaska-Secretary of Agriculture, Washington, D. C.; Arkansas -Secretary of State, Little Rock; Florida-Chas. G. Megargee, Umatilla, Lake County; Gcorgia-C. L. Davis, Warm Springs; Hawaii, D. B. Kuhns, Honolulu; Kentucky-E. H. Nobbe, 506 20th street, Louisville; Mississippi-Miles Carroll, Yazoo City; Nevada-Secretary of State, Carson City; Virginia-L. T. Christian, 1012 East Broad street, Richmond.

The game laws are published in pamphlet form in all the States except Georgia and Hawaii.]

\section{ALABA.MA.}

State Game and Fish Commissioner. Office established February 19, 1907; term, four years.

John H. Wallace, jr., Montgomery (term expires January, 1913).

Publications: Game Laws; Biennial Reports-last report, 1908.

\section{ALASKA.}

Game Warden. Office established May 11, 1908; appropriation first available July 1, 1909 ; term, pleasure of governor.

P. F. Vian, Kenai; Christopher C. Shea, Seward; A. R. Garner, Circle City.

ARIZONA.

Fish and Game Commissioners. Commission established 1887; term, two years.

Theo. T. Swift, Safford.

Secretary, W. L. Pinney, Phoenix.

V. V. Merino, Flagstaff. All terms expire April 1, 1911.

Publications: Game Laws.

\section{CALIFORNIA .}

Board of Fish and Game Commissioners. Board of Fish Commissioners established April 2, 1870; jurisdiction extended to game, 1878; title changed, 1909; term, pleasure of governor.

President, W. G. Henshaw, Oakland.

M. J. Connell, 405 South Hill street, Los Angeles.

Chief Deputy, John P. Babcock, Merchants' Exchange Building, San Francisco.

Office of the Board, Merchants' Exchange Building, San Francisco.

Fublications: Fish and Game Laws; Biennial Reports-last report, 1910.

[?ir. 74.] 
COLORADO.

State Game and Fish Commissioner. Office of State Fish Commissioner established March 10, 1877; juriscliction extended to game, 1891. Present office established April 27,1899 ; a term, two years.

Thomas J. Holland, Room 41, Capitol building, Denver (term expires April 1, 1911).

Deputy State Game and Fish Commissioner, James A. Shinn, Denver (term expires April 1, 1911).

Publications: Game and Fish Laws; Biennial Report-last report, 1908.

CONNECTICUT.

Commission of Fisheries and Game. Appointment of Commissioners on Fisheries first authorized in 1867. Jurisdiction extended to game, with establishment of present Commission, April 30, 1895; term, two years.

President, George T. Mathewson, Thompsonville.

Secretary, E. Hart Geer, Hadlyme.

E. Hart Fenn, Wethersfield. All terms expire July 1, 1911.

Office of the Commission, Room 66, State Capitol, Hartford.

Publications: Fish and Game Laws; Biennial Reports-last report, 1908.

DELAWARE.

Delaware Game Protective Association.b Incorporated March 28, 1879.

President, A. D. Poole, corner Seventh and West streets, Wilmington.

Secretary and Treasurer, Edward G. Bradford, jr., Equitable Building, Wilmington.

Publications: Game Laws.

DISTRICT OF COLUMBIA.

Metropolitan Police. $c$

Superintendent, Maj. Richard Sylvester, Washington.

Harbor Master, Lieut. Russell Deane, Washington.

IDAHO.

Fish and Game Warden. Office established March 13, 1899; term, two years.

Wm. N. Stephens, Boise (term expires March, 1911).

Chief Deputy, B. T. Livingston, Boise (until successor is appointed).

Fublications: Fish and Game Laws; Biennial Reports-last report, 1908.

ILLINOIS.

State Game Commissioner. Office established April 24, 1899; term, that of Governor (four years).

Dr. John A. Wheeler, Springfield (term expires January, 1913).

Publications: Game Laws.

INDIANA.

Commissioner of Fisheries and Game. Office of Commissioner of Fisheries established in 1881; jurisdiction extended to game and birds, and present office established February 13, 1899; term, four years.

George W. Miles, State House, Indianapolis (term expires May 3, 1911).

Publications: Fish and Game Laws; Biennial Reports-last report, 1908.

IOWA.

State Fish and Game Warden. Office established October 1, 1897; term, three years,

G. A. Lincoln, 234 Granby Block, Cedar Rapids (term expires March 31, 1913).

Publications: Fish and Game Laws; Biennial Reports-last report, 1908.

a From 1897 to 1899 the title was State Forest, Game, and Fish Commissioner.

$b$ Acts as a State Game Commission.

c Has jurisdiction over matters pertaining to game.

[Cir. 74.] 
KANSAS.

State Fish and Game Warden. Office of Commissioner of Fisheries established 1877.

Present office established July 1, 1905; term, four years.

Prof. L. L. Dyche, Lawrence (term expires June 30, 1913).

Publications: Fish and Game Laws.

\section{LOUISIANA.}

Board of Commissioners for the Protection of Birds, Game, and Fish. Established July 9 , 1908; term, four years.

President, Frank M. Miller, 605 Maison Blanche Building, New Orleans.

W. R. Dodson, Superintendent of State Experimental Station, Baton Rouge.

Fred R. Grace, Register of State Land Office, Baton Rouge.

Office of the Board, Court-House, New Orleans.

Publications: Fish and Game Laws.

MAINE.

Commissioners of Inland Fisheries and Game. Appointment of Commissioners of Fisheries authorized February 21, 1878; jurisdiction extended to game 1880.

Present Commission established March 8, 1899; term, three year:.

Chairman, J. W. Brackett, Phillips (term expires July 1, 1913).

Edgar E. Ring, Orono (term expires July 1, 1912).

Blaine S. Viles, Augusta (term expires July 1, 1913).

Office of the Commission, State Capitol, Augusta.

Publications: Fish and Game Laws; Biennial Reports-last report, 1908.

MARYLAND.

Game Warden. Office established April 4, 1896; reorganized April 10, 1904; term, two years.

Horace F. Harmonson, Atlantic Hotel, Berlin (term expires April, 1912).

Publications: Game and Fish Laws; Bulletins; Reports.

Board of Special (Ducking) Police.a Established 1872; reorganized 1880; term, two years.

Geo. T. Pennington, Havre de Grace, Harford County.

Jesse A. Price, Havre de Grace, Harford County.

Joseph Murphy, Charlestown, Cecil County.

John W. Quinn, Fair Hill, Cecil County.

Charles R. Ullary, jr., Elk Neck, Cecil County. All terms expire May, 1912.

Special Policeman (for protection of wildfowl on Elk and Bohemia rivers). Office established 1884; term, two year's.

Joseph Clay, Elkton, Cecil County (term expires May, 1912).

MASSACHUSETTS.

Commissioners of Fisheries and Game. Organized 1865; jurisdiction extended to game 1886 ; term, five years.

Chairman, Dr. George W. Field, State House, Boston (term expires December 28, 1914).

Superintendent of Hatcheries, John W. Delano, Marion (term expires December, 1910).

George H. Garfield, Brockton (term expires 1913).

Office of the Commission, Room 158, State House, Boston.

Publications: Fish and Game Laws; Annual Reports-last report, 1909.

\section{MICHIGAN .}

Game, Fish, and Forestry Department. Established as a Game and Fish Warden Department, March 15, 1887; reorganized 1907; term, four years.

Warden, Charles S. Pierce, Lansing (term expires 1911).

Chief Deputy, Charles N. Smith, Petoskey (term expires 1911).

Publications: Biennial Reports-last report, $\$ 908$.

a State officers appointed from Harford and Cecil counties for the protection of wildfowl on the Susque hanna Flats at the head of Chesapeake Bay.

[Cir. 74.] 
MINNESOTA.

Board of Game and Fish Commissioners. Appointment of Commissioners of Fisheries originally authorized March 5, 1874. Office of [State] Game Warden created March 8, 1887; term, four years. Present Board established April 20, 1891; term six years; reorganized 1901 ; term now, four years.

President, Robert Hannah, Fergus Falls (term expires 1911).

First Vice-President, Geo. J. Bradley, State Capitol, St. Paul (term expires 1914).

Second Vice-President, O. J. Johnson, Glenwood (term expires 1913).

Secretary, Jos. A. Wessel, Crookston (term expires 1912).

Executive Agent, H. A. Rider, St. Paul (term expires 1914).

Office of the Board, State Capitol, St. Paul.

Publications: Game and Fish Laws; Biennial Reports-last report, 1909.

\section{MISSOURI.}

Game and Fish Commissioner. Office of Game and Fish Warden established April 8, 1895; reorganized June 17, 1905; term, two years. Present office established August 16. 1909; term, four years.

Jesse A. Tolerton, Jefferson City (term expires August 16, 1913).

Publications: Game and Fish Laws; Annual Reports-last report, 1909.

\section{MONTANA.}

State Game and Fish Warden. Board of Game and Fish Commissioners established Warch 14, 1895; term, three years. Replaced by present office March 18, 1901; term, four years.

Henry A vare, Helena (term expires March, 1913).

Deputy, D. H. Morgan, Helena.

Publications: Game and Fish Laws; Biennial Reports-last report, 1906.

\section{NEBRASKA.}

Game and Fish Commission. Established July 1, 1901; term, two years.

Commissioner, Grov. Ashton C. Shallenberger, Lincoln (term expires January 1, 1911).

Chief Deputy, Dan Geilus, Lincoln (term expires January 1, 1911).

Publications: Game and Fish Laws; Biennial Reports-last report, 1908.

\section{NEW HAMPSHIRE.}

Board of Fish and Game Commissioners. Originally established as a Fish Commission June 30, 1865. Present Board established 1878; term, five years.

Chairman, Nathaniel Wentworth, Hudson (term expires 1912).

Financial Agent and Secretary, Charles B. Clarke, Concord (term expires February 11,1911 .

Frank P. Brown, Whitefield (term expires June 14, 1913).

Publications: Fish and Game Laws; Biennial Reports-last report, 1908.

NEW JERSEY.

Board of Fish and Game Commissioners. Appointment of Commissioners of Fisheries first authorized March 17, 1870; jurisdiction extended to game, 1894. Board of Fish and Game Commissioners established March 22, 1895; term, now four years.

President, B. C. Kuser, Trenton (term expires 1911).

Treasurer, Wm. A. Logue, Bridgeton (term expires 1912).

Percival Chrytie, High Bridge (term expires 1914).

Ernest Napier, East Orange (term expires 1913).

Secretary, Walter H. Fell, Trenton.

Fish and Game Protector, James M. Stratton, North Long Branch. Office of the Board and of Secretary, State Capitol, Trenton.

Publications: Fish and Game Laws; Annual Reports-last report, 1909.•

[Cir. 74.$]$ 
NEW MEXICO.

Game and Fish Warden. Office established March 12, 1903; term, two years.

Thomas P. Gable, Santa Fe (term expires April 1, 1911).

Publications: Fish and Game Laws, in English and Spanish.

NEW YORK.

Forest, Fish, and Game Commission. Originally established as a Commission of Fisheries in 1868. Office of Chief Game and Fish Protector created in 1888. Present commission established in 1895 and reorganized March 12, 1901; term, four years.

Commissioner, James S. Whipple, Albany (term expires April 15, 1912).

Deputy Commissioner, J. Duncan Lawrence, Bloomville (to serve with commissioner).

Secretary, John D. Whish, Albany (until successor is appointed).

Chief Game Protector, John B. Burnham, Essex (until successor is appointed).

Office of the Commission, The Capitol, Albany.

Publications: Forest, Fish, and Game Laws; maps; Annual Reports-last report, 1909.

\section{NORTH CAROLINA.}

Audubon Society of North Carolina.a Organized March 11, 1902; incorporated March 6, 1903.

President, Dr. R. H. Lewis, Raleigh.

Secretary, T. Gilbert Pearson, Greensboro.

Publications: State Game Law; circulars; Annual Reports-last report, 1909.

NORTH DAKOTA.

Game and Fish Board of Control. Established April 1, 1909; terms, two and four years. President, Herman Winterer, Valley City (term expires, April 1, 1913).

Vice-President, J. L. Killion, Towner (term expires April 1, 1911).

Secretary, D. I. Armstrong, Willow (ity (term expires April 1, 1911).

J. B. Eaton, Fargo (term expires April 1, 1913).

Thomas Griffiths, Grand Forks (term expires April 1, 1911).

Office of the Board and of Secretary, Willow City.

Districi Game Warden. Office originally established as State Game Warden in 1895; changed to District Game Warden in 1903; term, two yeare.

District No. 1 (northern). W. N. Smith, Grafton (term expires April 1, 1911).

District No. 2 (southern). Olaf Bjorke, Abererombie (term expires April 1, 1911).

Publications: Game and Fish Laws; Biennial Reports-last report, 1908.

онІо.

Commissioners of Fish and Game. Appointment of Commissioners of Fisheries first authorized May 3, 1873; jurisdiction extended to game with establishment of present Commission of 5 members May 17, 1886; term, five years.

President, Paul North, Cleveland (term expires May 17, 1913).

Dr. D. W. Greene, Dayton (term expires May 17, 1912).

Thomas B. Paxton, Cincinnati (term expires May 17, 1915).

Geo. W. McCook, Steubenville (term expires May 17, 1914).

J. F. Rankin, South Charleston (term expires May 17, 1911).

Chief Warden, Gen. John C. Speaks, Columbus (term expires May 1, 1911).

Office of the Commission, Columbus.

Publications: Fish and Game Laws; Annual Reports-last report, 1908.

\section{OKLAHOMA.}

State Game and Fish Warden. Office established March 10, 1899; term, four years.

J. S. Askew, Chickasha (term expires January 1, 1911).

Publications: Reports-last report, 1908.

a Acts as a State Game Commission. 
OREGION.

Game and Forestry Warden. Office of Game and Fish Protector established in 1893; term, two years. Present office established February 18, 1899; term, four years.

R. O. Stevenson, Forest Grove (term expires 1911).

Publications: Game Laws; Biennial Reports-last report, 1908.

PENNSYLVANIA.

Board of Game Commissioners. Board established 1895; term, three years.

President, James H. Worden, Harrisburg (term expires 1912).

C. K. Sober, Lewisburg (term expires November 17, 1911).

W'm. Heyward Myers, Williamsport (term expires 1912).

Dr. Charles B. Penrose, 1720 Spruce street, Philadelphia (term expires 1911).

John M. Phillips, 2227 Jane street, Pittsburg (term expires November 17, 1911).

Arthur Chapman, Doylestown (term expires 1911).

Secretary, Dr. Joseph Kalbfus, Harrisburg.

Office of the Board, The Capitol, Harrisburg.

Publications: Digest of Game and Fish Laws; Annual Reports-last report, 1909.

RHODE ISLAND.

Commissioners of Birds. Commission established June, 1899; term, three years.

Chairman, Charles H. Remington, 216 Waterman avenue, East Providence.

IV. Gordon Reed, 2d, Cowesett.

Dr. E. R. Lewis, Westerly.

William H. 'Thayer, Bristol.

All terms expire January 31, 1911.

Publications: Abstract of Game Laws; Annual Reports-last report, 1909.

SOUTH CAROLINA.

Chief Game Wrarden. Office established February 25, 1910; term, four years. (No appointment can be made until the meeting of the legislature in 1911.)

Audubon Society of South Carolina. ${ }^{a}$ Incorporated February 19, 1907.

President, M. O. Dantzler, Orangeburg.

Secretary, James Henry Rice, jr., Summerville.

Publications: State Game Laws; Annual Reports-last report, 1909.

SOUTH DAKOTA.

State Game Warden. Office established July 1, 1909; term, two years.

IV. F. Bancroft, Pierre (term expires July 1, 1911).

Publications: Game Laws.

TENNESSEE.

State Warden of Game, Fish, and Forestry. ${ }^{b}$ Office of State Warden established April 11, 1903; Department of Game, Fish, and Forestry established April 15, 1905; term, eight years.

Joseph H. Acklen, Nashville (term expires April 17, 1913).

Publications: Game, Fish, and Forestry Laws, and Reports-last report, 1908.

TEXAS.

Game, Fish, and Oyster Commissioner. Office of Fish and Oyster Commissioner established 1895; jurisdiction extended to game 1907.

R. H. Wood, Rockport.

Chief Deputy, R. W. Lorance, Austin.

Office of the Game Commissioner, Austin.

Publications: Game Laws.

a Acts as a State Game Commission.

$b$ The act passed at the session of the legislature in 1909 (Laws 1909, chap. 519, p. 1856) making the Commissioner of $\Lambda$ griculture ex-officio State Warden, has been declared unconstitutional by the Supreme Court of Tennessee.

[Cir. 74.] 
UTAH.

State Fish and Game Commissioner. Office of State Fish and Game Warden established 1897; term, two years. Present office established March 9, 1899; term, two years.

Fred W. Chambers, Salt Lake City (term expires April 5, 1911).

Publications: Fish and Game Laws; Biennial Reports-last report, 1908.

VERMONT.

Fish and Game Commissioner. Fish Commission established 1867; reorganized as a Fish and Game Commission November 22, 1892. Present office established December 7, 1904; term, two years.

Henry G. Thomas, Stowe (term expires November 30, 1910).

Publications: Fish and Game Laws; Biennial Reports-last report, 1908.

WASHINGTON .

State Fish Commissioner and Game Warden. Office of Game Warden established February 6, 1890; term, four years. Present office established March 13, 1899; term, four years.

John L. Riseland, Bellingham (term expires April 1, 1911).

Chief Deputy State Game Warden, Gus. Johnson, Bellingham.

Publications: Fish, Oyster, and Game Laws; Annual Reports-last report, 1908.

WEST VIRGINIA.

Forest, Game, and Fish Warden. Office of Game and Fish Warden established May 18, 1897; reorganized, 1909; term, four years.

J. A. Viquesney, Belington (term expires April, 1913).

Publications: Game and Fish Laws; Annual Reports--last report, 1908.

WISCONSIN.

State Warden. Office established May 5, 1891; term, two years.

Capt. George W. Rickeman, Madison (term expires June, 1911).

Pubications: Fish and Game Laws.

WYOMING.

State Game Warden. Office of Fish Commissioner established $1879 ;$ jurisdiction extended to game, 1895. Present office established February 15, 1899; term, four years.

D. C. Nowlin, Lander (term expires February 20, 1911).

Publications: Game and Fish Laws; Annual Reports-last report, 1909.

\section{CANADA.}

ALBERTA.

Department of Agriculture. $b$ Office of Chief Game Guardian established 1905.c

Minister, Duncan Marshall, Edmonton.

Chief Game Guardian, Benjamin Lawton, Edmonton.

Publications: Game J_aws; Annual Reports-last report, 1909.

BRITISH COLUMBIA.

Provincial Game and Forest Warden. Office established 1905.

A. Bryan Williams, Fairfield Building, Vancouver.

Publications: Game Laws; Annual Reports-last report, 1909.

a From 1882 to 1884 the duties were performed by a board of six Fish Commissioners.

$\checkmark$ Has jurisdiction over matters pertaining to gaine.

c Prior to 1905 the duties were performed by the Chief Game Guardian of the Northwest Territories, an officer first appointed in 1902.

[Cir. 74.] 
MANITOBA.

Department of Agriculture and Immigration.a Office of Chief Game Guardian estahlished Angust, 1898.

Minister, R. P. Roblin, Winnipeg.

Chief Game Guardian, Charles Barber, Winnipeg.

Publications: Game Protection Act; Annual Reports-last report, 1908.

\section{NEW BRUNSWICK.}

Crown Land Department.a Office of Chief Game Commissioner established 1878; title changed to Chief Wardens, 1909.

Surveyor-General W. C. H. Grimmer, St. Stephen.

Deputy Surveyor-General, T. G. Loggie, Fredericton.

Chief Fishery, Game, and Fire Wardens:

District No. 1, Dennis Doyle, Newcastle.

District No. 2, A. E. O'Leary, Richubucto.

District No. 3, W. J. Dean, Musquash.

District No. 4, John McGibbon, St. Stephen.

Overseer of Fisheries, S. U. McCully, Chatham.

Publications: Game Laws; Annual Repurts-last report, 1908.

NEWFOUNDLAND.

Department of Marine and Fisherics.a Established March 10, 1898.

Game Preservation and Inland Fisheries Board (15 members) authorized May 10, 1906; organized 1909.

Minister, A. IT. Piccott, St. Johns.

Deputy Minister, A. C. Goodridge, St. Johns.

Secretary of Fisheries Poard, Judge D. W. Prowse, Box 118i, St. Johns.

President of Game Preservation Board, Minister of Marine and Fisheries.

Publications: Annual Reports-last report, 1908.

NOVA SCOTIA.

Board of Game Commissioners. Establisher April 16, 1905. (Duties formerly exercised by Nova Scotia Game and Inland Fishery Protection Society.)

Chiei Game Commissioner, J. A. Knight, St. Paul Building, Halifax.

Associate Commissioners, A. O. Pritchard, New Glasgow; C. R. Kelly, Yarmouth.

ONTARIO.

Depurtment of Public Work-Game and Fisheries Branch. Office of Chief Game Warden established 1892; office of Superintendent of Game and Fisheries established 1907.

Minister, J. O. Reaume, Parliament Buildings, Toronto.

Superintendent of Game and Fisheries, F. Tinsley, Parliament Buildings, Toronto.

Publications: Game Laws; Annual Reports-last report, 1908.

Gume and Fisheries Commission. Established, 1909.

Commissioner, Kelly Evans, Empire Building, 64 Wellington street west, Toronto.

Publicutions: Interim report, 1910.

PRINCE EDWARD ISLAND.

Game Inspector. Office established April 21, 1906; term, pleasure of LieutenantGovernor in Council.

E. T. Carbonell, Box 85, Charlottetown.

Publications: Annual Reports-last report, 1908 .

[Cir. 74.] 
QUEBEC.

Department of Colonization, Mines, ard Fisheries-Fisheries and Game Branch. Office of Game Superintendent established June 10, 1884; reorganized in 1897 and 1906.

Minister, Charles Devlin, Quebec.

Deputy Minister, J. Dufault, Quebec.

General Superintendent of Fisheries and Game, Hector Caron, Queber.

Assistant Superintendent of Fisheries and Game, Eug. Hamel, Quebec.

General Inspector of Fisheries and Game, J. A. Bellisle, Queber:

Publications: Fish and Game Laws, in French and English; Annual Reports-last report, 1908.

SASKATCHEWAN.

Department of Agriculture ${ }^{a}$ Office of Chief Game Guardian established $1905 ; b$ term, pleasure of Commissioner of Agriculture.

Minister of Agriculture, IT. R. Motherwell, Regina.

Deputy Minister, IT. J. Rutherford, Regina.

Chief Game Guardian, ___ _....., Regina.

Publications: Annual Reports-last report, 1908.

\section{NATIONAL ORGANIZATIONS.}

American Bison Society. Organized December 8, 1905.

President, William T. Hornaday, 185th street and Southern Boulevard, New York, N. Y.

Secretary, William P. Wharton, Groton, Mass.

American Ornithologists' Union. Committee on Protection of North AmeriCAN Birds. Established October 1, 1884.

Chairman, A. K. Fisher, Departnent of Agriculture, Washmgton, D. C.

Boone And Crockert Club. Founded December, 1887.

[One of the objects of the club is the preservation of the large game of this country by furthering legislation for that purpose, and by assisting in enforcing existing laws.]

President, W. A. Wartsworth, Geneseo, N. Y.

Secretary, Madison Grant, 11 Wall street, New York, N. Y.

Camp Fire Club of Anerica. Organized 1903; incorporater 1904.

President, Ernest Thompson Seton, Cos Cob, Conn.

Secretary, Arthur F. Rice, Flatiron Puilding, New York, N. Y.

League of American Sportsmen. Organized January 19, 1899; incorporated June 1, 1898.

President, G. O. Shields, 1061 Simpson street, New York, N."Y.

Secretary, H. M. Beach, 1061 Simpson street, New York, N. Y.

Lewis axd Clark Club. Organized January, 1905.

President, Wm. M. Kennedy, 327 Fourth avenue, Pittsburg, Pa.

Secretary and Treasurer, Wm. S. Brown, 523 Wood street, Pittsburg, Pa.

National Association of Audubox Societies. Organized as a national committee April 4, 1902; incorporated January 5, 1905.

President, William Dutcher, 141 Rroadway, New York, N. I.

Secretary, T. Gilbert Pearson, Greensboro, N. C.

Office of the Association, 141 Broadway, New York, N. Y.

National Association of Game and Fish Wardens. Organized July 20, 1902; reorganized February 11, 1904.

President, T. Gilbert Pearson, Greensboro, N. C.

Secretary, Dr. George IV. Field, Room 158 State House, Boston, Mass.

New York Zoological Socie'ry. Incorporated April 26, 1995.

[This society takes an active part in the protection of birds and game.]

President, Prof. Henry Fairfield Osborn, 850 Madison avenue, New York, N. Y. Secretary, Madison Grant, 11 Wall street, New York, N. Y.

$a$ Has jurisdiction over matters pertaining to game.

$b$ Prior to 1905 the duties were performed by the Chief Game Guardian of the Northwest Territories, an officer first appointed in 190?.

[Cir. 74.] 
North American Fish and Game Protective Association. Organized January $30,1900$.

President, Sir Lomer Gouin, Quebec.

Secretary-treasurer, E. T. D. Chambers, Quebec.

\section{STATE ORGANIZATIONS.}

California Game and Fish Protective Association. Organized May 26, 1900. President, H. W. Keller, 668 Pacific Electric Building, Los Angeles.

Secretary, A. R. Orr, Visalia.

Colorado Sportsmen's Association. Organized February 9, 1909.

President, J. F. Engel, 1175 Stout street, Denver.

Secretary, T. F. Dolan, Box 1722, Denver.

Connecticut Fish and Game Protective Association. Organized June 17, 1909. Incorporated September 10, 1909.

President, Theodore Sturgis, Fairfield.

Secretary and Treasurer, H. P. Carter, New Britain.

Delaware Game Protective Association. (See p. 3.)

Game and Fish Protective Association of the District of Columbia. Organized February 3, 1897.

President, Dr. IV. S. Harban, 1339 K street NV., Washington.

Secretary-treasurer, Dr. W. P. Young, 419 Tenth street NiW., Washington.

Georgia State Game and Fish Protective Associatiox. Orgmized May 18, 1909.

President, C. L. Davis, Warm Springs.

Secretary, Barschall Andrews, Columbus.

Iowa Fish and Game Protective Association. Incorporated May 14, 1908.

President, M. C. Matthews, Dubuque.

Secretary, Jules C. Gregoire, 639 Main street, Dubuque.

Kentucky Fish and Game Protective Association. Organized February 22, 1909.

President, Joseph G. Sachs, Sachs Law Building, Louisville.

Secretary, E. H. Nobbe, 506 Twentieth street, Louisville.

Maine Sportsmen's Fish and Game Association. Chartered 1893.

President, John F. Sprague, Monson.

Secretary and Treasurer, F. R. Smith, Pittsfield.

Maryland State Game and Fish Protective Association. Organized March 5, 1895; incorporated May 13, 1898.

President, George Dobbin Penniman, B. and O. Building, Baltimore.

Secretary and Attorney, Talbott Denmead, 213 St. Paul street, Baltimore.

Massachusetts Fish and Game Protective Association. ('hartered March 29. 1877.

[Formerly the Massachusetts Anglers' $\Lambda$ ssociation. Chartered March 1S, 18it.]

President, Salem D. Charles, City Hall, Boston.

Secretary, Henry H. Kimball, 748 Tremont Building, Boston.

The Michigan Association. Organized April 19, 1907.

President, W. B. Mershon, Saginaw.

Secretary, Fred K. George, Detroit.

Michigan State Game and Fish Protective League. Organized $18 s 0$.

President, R. S. Woodliff, Jackson.

Secretary and Treasurer, W. C. Sterling, jr., Monroe.

Missouri Game and Fish Protective League. Organized February ¿6, 1902; incorporated July 2, 1902.

President, A. E. Winkelmeyer, Union liscuit Co., Sixth and Carr strect, St. Louis.

Corresponding Secretary, E. T. Grether, 6412 Etzel arenue, St. Louis.

[Cir. 74.] 
State League of Missouri Sportsuen. Organized November, 1908.

President, Judge J. E. Guinotte, Kansas City.

Secretary, H. R. Walmsley, 205 Sheidley Building, Kansas City.

Montana Fish and Game Protective Association. Organized January 27, 1901.

President, Richard A. Harlow, Helena.

Secretary, A. L. Palmer, Helena.

Association of New Jersey Sportsmen for the Protection and Propagation of GaMe. Organized October 12, 1907.

President, George Batten, 93 Union street, Montclair.

Secretary, Edward Winslow, 180 Walnut street, Montclair.

New York Association for the Protection of Game. Founded May 20, 1844; incorporated 1884.

President, Col. Alfred Wagstaff, 29 Madison avenue, New York.

Secretary, Robert B. Lawrence, 45 Broadway, New York.

New York State Fish, Game, and Forest League. Organized 1897; incorporated April 16, 1898.

[Formerly the New York State Association for the Protection of Fish and Game. Organized 1865.]

President, Charles R. Skinner, Watertown.

Secretary, L. C. Andrews, Elmira.

North Dakota Game and Fish Protective Association. Organized May 22, 1907.

President, W. IV. Cook, Fargo.

Secretary, W. B. Bell, Agricultural College.

[Ohio] Cuvier Club of Cincinnati. Organized February 5, 1S74; incorporated June 21, 1881.

[Formerly the Ohio State Society for the Protection of Game and Fish. Organized June 14, 18i1.]

President, John E. Bruce, Cuvier Club, Cincinnati.

Secretary, Edwin B. Innes, Cuvier Club, Cincinnati.

Orlahoma State Game and Fish Protective Association. Organized December 11, 1908.

President, S. H. Harris, Oklahoma City.

Secretary, J. C. Clark, Oklahoma City.

Uregon Fish and Game Association. Organized January 28, 1899.

President, Dr. P. S. Langworthy, First and Morrison streets, Portland.

Secretary, A. E. Gebhardt, 424 Chamber of Commerce Building, Portland.

United Sportsmen of Pennsyluania. Organized April 1, 1908.

President, Hon. Oscar E. Thompson, Phoenixville.

Secretary, W. E. Meehan, Box 89, Harrisburg.

Tennessee Game and Fish Protective Association. Incorporated December $20,1904$.

President, Joseph H. Acklen, Nashville.

Secretary and Treasurer, Thomas M. Hart, Nashville.

Texas Game Protective Association. Organized April, 1906.

[The original association of this name was organized in September, 1896.]

President, J. J. Stevens, San Antonio.

Secretary, Col. O. C. Guessaz, San Antonio.

Vermont Fish and Game League. Incorporated November 21, 1890.

President, Maxwell Evarts, 120 Broadway, New York, N. Y.

Secretary, H. G. Thomas, Stowe, Vt.

Eastern Shore Game Protective Association of Virginia. Organized 1893; incorporated March, 1894.

President, J. W. Bowdoin, Bloxom.

Secretary and Treasurer, T. W. Blackstone, Accomac.

Game Protective Association of Virginia. Organized February 15, 1905.

President, Dr. J. B. Fisher, Midlothian.

Secretary-treasurer, L. T. Christian, 1012 East Broad street, Richmond.

[Cir. 74.$]$ 
Washington State Gaine and Fish Protective Association. Organized December 4, 1903; incorporated.

President, Frank A. Pontius, Seattle.

Secretary-treasurer, H. Rief, 320 Jefferson street, Seattle.

West Virginia Fish and Gane Protective Association. Organized November 14, 1906.

President, R. H. Smith, Ronceverte.

Secretary-treasurer, L. C. Crile, Clarksburg.

Wisconsin Game Protective Association. Organized 1899.

President, Joseph Fischer, 818 Thirty-first street, Milwaukee.

Secretary, G. A. Raeth, $893 \frac{1}{2}$ Twenty-sixth street, Milwaukee.

[Wisconsin] Northwestern Game Protective Association. Organized December 5, 1904.

President, Gen. Joseph B. Doe, 309 Wells Building, Milwaukee.

Secretary, E. L. Tracy, 815 Pabst Building, Milwaukee.

Wisconsin State Gaile and Fish Protective Association. Organized March 23, 1909.

President, Edward L. Kelley, Manitowoc.

Secretary, H. C. Berndt, Manitowoc.

Fish and Game Protective Association of Alberta. Organized January, 1907.

President, R. A. Darker, Calgary.

Secretary-treasurer, Dr. E. Sisley, Calgary.

Manitoba Game Protective Association. Organized 1905.

President, A. L. Hamilton, Portage la Prairie.

Secretary-treasurer, J. P. Turner, 339 Main street, Winnipeg.

New Brunswick Fish, Forest, and Game Protective Association. Organized June 12, 1907.

President, C. Fred. Chestnut, Fredericton.

Secretary, J. J. F. Winslow, Fredericton.

Nova Scotia Game and Inland Fishery Protection Society. Organized March $18,1853$.

President, L. G. Power, Halifax.

Secretary-treasurer, Harris L. Tremaine, Queen Building, Halifax.

People's Game and Fish Protective Association of Nova Scotia. Organized November 11, 1906.

President, H. D. Ruggles, Annapolis.

Secretary and treasurer, Frank W. Russell, Halifax.

Ontario Forest, Fish and Game Protective Association. Organized June 7, 1905.

Acting President, Oliver Adams, 55 Glen Road, Toronto.

Secretary-treasurer, Kelly Evans, Empire Building, 6t Wellington street west, Toronto.

Prince Edward Island Game and Fish Protective Association. Organized September 1, 1905. Incorporated April 21, 1906.

President, Albert E. Morrison, Charlottetown.

Secretary, E. T. Carbonell, Box 85, Charlottetown.

Province of Quebec Association for the Protection of Fish and Gaie. Organized February 23, 1859.

President, IV. L. Maltby, Montreal.

Secretary, J. R. Innes, Imperial Bank Building, Montreal.

Sportsuen's Fish and Game Protective Association of the Protince of QueBEr. Incorporated 1901.

President, E. G. Joly de Lotbinière, Quebec.

Secretary, E. T. D. Chambers, Quebec.

Saskatchewan Gaie Protective Association. Organized August 10, 1906.

President, Dr. D. Low, Regina.

Secretary, IV. M. Van Valkenburg, Regina.

[Cir. 74.] 


\section{AUDUBON SOCIETIES. $a$}

[Organized for the study and protection of birds. Societies not heard from in 1910 are marked wiih an $\operatorname{asterisk}(*)$.]

AlABAMA.

President,

Secretary,

Arizona. Organized April, 1908.

President, Herbert Brown, Tucson.

Secretary, Mrs. Harriet B. Thornber, Tucson.

Califorvia. Organized May 31, 1906.

[Local societies organized at Redlands April 17, 18.99, and Pasadena March 25, 1904.]

President, Dr. David Starr Jordan, Stanford University.

Secretary, Mrs. Harriet IV. Myers, 306 Avenue 66, Los Angeles.

Connecticut. Organized January 28, 1898.

President, Mrs. Mabel Osgood Wright, Fairfield.

Secretary, Mrs. William Brown Glover, Fairfield.

Delaware. Organized April, 1900.

President, A. D. Poole, corner Seventh and West streets, Wilmington.

Secretary, Mrs. Wm. S. Hilles, 904 Market street, Wilmington.

District of Columbia. Organized May 18, 1897

President, Hon. Job Barnard, 1306 Rhode Island avenue, Washington, D. C.

Secretary, Miss Helen P. Childs, Chevy Chase, Md.

Florida. Organized March 2, 1900.

President, L. F. Dommerich, Maitland.

Secretary, Mrs. I. Vanderpool, Maitland.

Illixors. Organized April 1, 1897.

President, Ruthven Deane, Room 913, 135 Adams street, Chicago.

Secretary-treasurer, Miss Mary Drummond, Spring Lane, Lake Forest.

Indiana. Organized April 26, 1898.

President, Amos $\mathrm{T}^{*}$. Butler, 52 State House, Indianapolis.

Secretary, Miss Florence A. Howe, 2043 Hillside avenue, Indianapolis.

IowA. Organized April 5, 1898.

President, Mrs. W. B. Small, Waterloo.

Secretary, Mrs. William F. Parrott, 302 Franklin street, Waterloo.

Kansas. Organized October 2, 1908.

President, Richard II. Sullivan, Wichita.

Secretary, Frank E. McMullen, Wichita.

Loursiana. Organized November, 1902.

President, Prof. Geo. E. Beyer, Tulane University, New Orleans.

Secretary, Mrs. Percival Wraight, 460 Pine street, New Orleans.

MAINE. Organized July 31, 1902.

President, Prof. A. L. Lane, East Winthrop.

Secretary, Arthur H. Norton, 22 Elm street, Porlland.

MARYLAND. Organized 1906.

President, Miss Isabel Crawford Tudor, 2410 North Charles street, Baltimore. Secretary, Miss Minna D. Starr, 2400 North Charles street, Baltimore.

MassachusetTs. Organized January, 1896.

President, William Brewster, 145 Brattle street, Cambridge.

Secretary and Treasurer, Miss Jessie E. Kimball, Boston Society of Natural History, Boston. 
Michigan. Organized February, 1904.

President, Wm. Aikman, jr., 4 Walker Block, Detroit.

Secretary, Jefierson Butler, 121 Phi!adelphia avenue, West Detroit.

Minnesota. Organized June 1, 1897.

President, D. Lange, 2308 Commonwealth avenue, St. Pảul.

Secretary,

Mississippi. Organized November 13, 1907.

President, Wm. Hemingway, Jackson.

Secretary,

Missouri. Organized June 14, 1901; reorganized December 10, 1907.

President, H. R. Walmsley, 318 Keith \& Perry Building, Kansas City.

Secretary,

Nebraska. Organized June, 1902.

President, Dr. Solon R. Towne, Continental Building, Omaha.

Secretary, Miss Joy Higgins, 2961 Pacific street, Omaha.

New Hampshire. Organized April 6, 1897.

President, Mrs. Arthur E. Clarke, North River road, Manchester.

Secretary, Miss Sarah Hazard, 100 Harrison street, Manchester.

New Jerser. Organized May, 1897.

President, Alexander Gilbert, 318 West Eighth street, Plainfield.

Secretary, Miss Julia S. Scribner, 510 East Front street, Plainfield.

New York. Organized February 23, 1897; incorporated November 23, 1904.

President, Prof. Henry Fairfield Osborn, 850 Madison avenue, New York.

Secretary, Miss Emma H. Lockwood, 243 West Seventy-fifth street, New York.

North Carolina. Organized March 11, 1902; incorporated March 6, 1903. (See p. 6.)

North Dakota. Grand Forks Society organized 1903; State society organized April, 1904.

President, Dr. O. G. Libby, Grand Forks.

Secretary, Mrs. G. F. Ruediger, South Fourth street, Grand Forks.

OHio. Organized December 14, 1898; incorporated March 22, 1900.

President, J. P. Cummins, Evans place, Cincinnati.

Secretary, Miss Katherine Ratterman, 510 York street, Cincinnati.

OkLahoma. Organized 1902; incorporated June 16, 1906; reorganized June 25, 1907.

President, Neill Humphrey, Guthrie.

Secretary, Miss Ama Carson, Guthrie.

Oregon. Organized July 1, 1902; incorporated 1909.

[Formerly the John Burroughs Bird Society, organized in 1900.]

President, IV. I. Finley, Milwaukee.

Secretary, Dr. Emma J. Welty, 321 IIontgomery street, Portland.

Penxsylvania. Organized October, 1896.

President, Witmer Stone, Academy of Natural Sciences, Philadelphia.

Secretary, Miss Elizabeth Wrlson Fisher, Room 22, 524 Walnut street, Philadelphia.

*Rhode Island. Organized October, 1897.

President, Dr. Albert D. Mead, Brown University, Providence.

Secretary, Miss Alice W. Wilcox, 165 Prospect street, Providence.

South Carolina. Organized January 4, 1900; incorporated l'ebruary 19, 1907. (See p. 7.)

South Dakota. Organized March, 1907.

President,

Secretary, George A. Pettigrew, Sioux Falls.

[Cir. 74.] 
Texas. Organized 1903.

President, J. B. Sawtelle, Waco.

Secretary, M. B. Davis, Waco.

Vermont. Organized September 2, 1901.

President, Prof. J. W. Votey, University of Vermont, Burlington.

Secretary, Carleton D. Howe, Essex Junction.

VIRGINIA. Organized December 11, 1908.

[Local societies organized at Glen Carlyn June 3, 19.31, and Falls Church September 29, 1903.]

President, Mrs. Moses D. Hoge, jr., 308 East Grace street, Richmond.

Secretary, Mrs. A. S. Buford, jr., 20 Franklin street, Richmond.

Washington. Organized April 20, 1907.

President, James Illingworth, 2201 Harvard avenue north, Seattle.

Secretary, H. Rief, 320 Jefferson street, Seattle.

Wisconsin. Organized April 20, 1897; reorganized June 10, 1908.

President, R. H. Denniston, State University, Madison.

Secretary-treasurer, Charles E. Brown, State Historical Museum, Madison.

\section{INTERNATIONAL COMMITEE FOR THE PROTECTION OF BIRDS.}

[Appointed at the Fifth International Ornithological Congress at Berlin, June 4, 1910.]

Chairman: Dr. Heuss, Leostrasse 33, Paderborn, Germany.

Austria. Prof. Bruno Schweder, Weisskirchen.

Bavaria. Freiherr von Gebsattel, Bamberg.

BELGIUM:

Dr. Alphonse Dubois, 61 Rue de la Vallee, Brussels.

Madame C. van Hoorde, 61 Rue de la Vallee, Brussels.

Denmark. Lieutenant-Colonel Mehrn, Copenhagen.

France:

Dr. A. Ménégaux, Museum Histoire Naturelle, Paris.

Louis Ternier, Honfleur, Calvados.

GERMANY:

Baron von Berlepsch, Schloss Berlepsch, Post Gertenbach, Witzenhausen.

Dr. - Heuss, Leostrasse 33, Paderborn.

Great Britain:

Lord Avebury, London.

James Buckland, Royal Colonial Institute, Northumberland avenue, London, IV. C.

HOLLAND:

F. J. A. van Vollenhoven, Orangesingel 3, Nijmegen.

Prof. Dr. J. Ritzema-Bos, Wageningen.

Hungary. Stefan Chernel von Chernelháza, Köszeg.

Italy. Count Arrigoni Degli Oddi, University of Padua, Padua.

Norway. Oberhofstallmeister Sverdrup.

RUSSIA:

F. E. Stoll, Grosse Küterstrasse 18, Riga.

Baron Harald Loudon, Lisden bei Wolmar, Livland.

Sweden. Prof. Dr. Einar Lönnberg, Vetenskapsakademien, Stockholm.

United States:

Wm. Dutcher, 141 Broadway, New York.

T. S. Palmer, Department of Agriculture, Washington, D. C.

[Cir. 74.] 